\title{
Mobile Colistin Resistance Gene $m c r-1$ Detected on an IncI2 Plasmid in Salmonella Typhimurium Sequence Type 19 from a Healthy Pig in South Korea
}

\author{
Dong Chan Moon (D), Su-Jeong Kim, Abraham Fikru Mechesso, Hee Young Kang, Hyun-Ju Song, Ji-Hyun Choi, \\ Soon-Seek Yoon (D) and Suk-Kyung Lim *
}

Bacterial Disease Division, Animal and Plant Quarantine Agency, 177 Hyeksin 8-ro, Gimcheon-si 39660, Korea; ansehdcks@korea.kr (D.C.M.); kimsujeong27@gmail.com (S.J.K.); abrahamf@korea.kr (A.F.M.); kanghy7734@korea.kr (H.Y.K.); shj0211@korea.kr (H.-J.S.); wlgus01@korea.kr (J.-H.C.); yoonss24@korea.kr (S.-S.Y.)

* Correspondence: imsk0049@korea.kr; Tel.: +82-54-912-0738

Citation: Moon, D.C.; Kim, S.-J.; Mechesso, A.F.; Kang, H.Y.; Song, H.-J.; Choi, J.-H.; Yoon, S.-S.; Lim, S.-K. Mobile Colistin Resistance Gene $m c r-1$ Detected on an IncI2 Plasmid in Salmonella Typhimurium Sequence Type 19 from a Healthy Pig in South Korea. Microorganisms 2021, 9, 398. https://doi.org/10.3390/ microorganisms 9020398

Academic Editor: Jens André Hammerl

Received: 28 January 2021 Accepted: 12 February 2021 Published: 15 February 2021

Publisher's Note: MDPI stays neutral with regard to jurisdictional claims in published maps and institutional affiliations.

Copyright: (c) 2021 by the authors. Licensee MDPI, Basel, Switzerland. This article is an open access article distributed under the terms and conditions of the Creative Commons Attribution (CC BY) license (https:// creativecommons.org/licenses/by/ $4.0 /)$.

\begin{abstract}
Colistin is considered the last resort for the treatment of multi-drug resistant Gram-negative bacterial infections. We studied colistin resistance and the $\mathrm{mcr}-1$ gene carriage in Salmonella isolates recovered from food animals in South Korea between 2010 and 2018. Colistin resistance was found in 277 isolates, predominantly in Salmonella Enteritidis (57.1\%) and Salmonella Gallinarum (41.9\%). However, the $m c r-1$ gene was identified in only one colistin-resistant Salmonella Typhimurium (MIC $=16 \mu \mathrm{g} / \mathrm{mL}$ ) isolated from a healthy pig. The $m c r-1$ carrying isolate presented additional resistance to multiple antimicrobials. The strain belonged to sequence type (ST)19 and carried various virulence factor genes that are associated with adhesion and invasion of Salmonella into intestinal epithelial cells, as well as its survival in macrophages. The $m c r-1$ gene was identified on an IncI2 plasmid and it was also transferred to the E. coli J53 recipient strain. The mcr-1-carrying plasmid (pK18JST013) in this study was closely related to that previously reported in S. Indiana (pCFSA664-3) from chicken in China. This is the first report of $m c r-1$ carrying $S$. Typhimurium in South Korea. The finding indicates the importance of regular screening for the presence of the $m c r-1$ gene in $S$. Typhimurium in food animals to prevent the spread to humans.
\end{abstract}

Keywords: colistin resistance; mcr-1; pig; plasmid; Salmonella Typhimurium

\section{Introduction}

Non-typhoidal Salmonella serovars are common causes of foodborne diseases, especially in the elderly, children, and immunocompromised individuals [1]. Non-typhoidal Salmonella-associated enterocolitis was associated with 95 million illnesses and 50,000 deaths globally in 2017, and most of the cases were foodborne [2]. In South Korea (Korea), Salmonella was detected in about $8 \%$ of gastroenteritis cases in 2017 [3]. Contaminated food products from food animals are the most common sources of human infections [1].

Colistin belongs to the group of polymyxins and has been used for the treatment and prevention of gut infections in food animals particularly poultry and pigs. In humans, although their parenteral usage has been limited because of concerns of toxicity, it is the last resort treatment for severe infections caused by multi-drug resistant (MDR) Gram-negative bacteria, particularly carbapenem-resistant Enterobacteriaceae [4]. Colistin use in animals has promoted the selection and transmission of $m c r$-harboring strains [5]. The $m c r$ genes encode phosphoethanolamine transferases that modify the lipopolysaccharides of the outer membrane in Gram-negative bacteria, which leads to reduced susceptibility or resistance to colistin [5].

Since the first report of the mcr-1 gene in Escherichia coli in China in 2016 [6], the MCRfamily genes have been detected in several other Enterobacteriaceae in many countries [7]. 
The $m c r-1$ and $m c r-9$ are the most widely disseminated MCR-family genes, being identified in 40 countries across six continents; $m c r-3$ and $m c r-5$ are the next most widely spread genes. The remaining MCR-family genes are disseminated across small areas [7]. In Korea, $m c r-1, m c r-3$, and $m c r-9$ genes were identified in Enterobacteriaceae isolated mainly from food animals [8-10].

Several studies have identified the $m c r-1$ harboring Salmonella from patients, food and companion animals, and food of animal origin in Asia [11-14], Europe [15,16], and South America [17,18]. In Korea, however, this gene has been detected only in E. coli and Enterobacter aerogenes isolated from humans, food and companion animals, and fresh vegetables [8,19-21]. The $m c r-1$ gene was so far associated with diverse plasmids belonging to the IncI2, IncHI1, IncHI2, IncP1, IncX4, IncFII, and IncY replicon types. Among them, IncHI2 and IncI2 plasmids were the most common replicons in Salmonella spp [22]. In view of the concerning horizontal spread of the $\mathrm{mcr}$ - 1 gene among Enterobacteriaceae in food animals and its significant public health impacts, we performed a retrospective evaluation of colistin resistance and investigated the mcr-1-carrying plasmid in Salmonella isolated from food animals between 2010 and 2018 in Korea.

\section{Materials and Methods}

\subsection{Identification of Colistin-Resistant and mcr-1 Carrying Salmonella Serotypes}

Recently, we identified and serotyped 3018 Salmonella isolates recovered from cattle, pigs, and chickens throughout Korea from 2010 to 2018. Isolates were obtained from 16 laboratories/centers participating in the Korean Veterinary Antimicrobial Resistance Monitoring System [23]. In this study, we performed a retrospective evaluation of the colistin susceptibility profiles of these isolates. The minimum inhibitory concentration (MIC) of colistin was determined by the broth microdilution method using Sensitire panel KRNV5F (Trek Diagnostic Systems, Cleveland, OH, USA), following the manufacturer's instructions. Additionally, multiplex-polymerase chain reaction (mPCR) analysis was performed to determine the $\mathrm{mcr}$ gene $(m c r-1$ to $m c r-9)$ carriage of colistin-resistant serotypes, as described previously [24,25].

\subsection{Characterization of mor-1-Carrying Isolate}

We investigated the susceptibility profiles of the $m c r-1$-carrying isolate as described above. The following antimicrobials were studied: amoxicillin/clavulanic acid (2/1$32 / 16 \mu \mathrm{g} / \mathrm{mL})$, ampicillin $(2-64 \mu \mathrm{g} / \mathrm{mL})$, cefepime $(0.25-16 \mu \mathrm{g} / \mathrm{mL})$, cefoxitin $(1-32 \mu \mathrm{g} / \mathrm{mL})$, ceftazidime (1-64 $\mathrm{g} / \mathrm{mL})$, ceftiofur $(0.5-8 \mu \mathrm{g} / \mathrm{mL})$, chloramphenicol $(2-64 \mu \mathrm{g} / \mathrm{mL})$, ciprofloxacin $(0.12-16 \mu \mathrm{g} / \mathrm{mL})$, colistin $(2-16 \mu \mathrm{g} / \mathrm{mL})$, gentamicin $(1-64 \mu \mathrm{g} / \mathrm{mL})$, meropenem $(0.25-4 \mu \mathrm{g} / \mathrm{mL})$, nalidixic acid $(2-128 \mu \mathrm{g} / \mathrm{mL})$, streptomycin $(16-128 \mu \mathrm{g} / \mathrm{mL})$, sulfisoxazole $(16-256 \mu \mathrm{g} / \mathrm{mL})$, tetracycline $(2-128 \mu \mathrm{g} / \mathrm{mL})$, and trimethoprim/sulfamethoxazole $(0.12 / 2.38-4 / 76 \mu \mathrm{g} / \mathrm{mL})$. The MIC values were interpreted according to the Clinical and Laboratory Standards Institute [26] and the European Committee on Antimicrobial Susceptibility Testing [27] guidelines.

Multilocus sequence typing was performed as described previously [28]. Sequence type (ST) was assigned using the multilocus sequence typing website for Salmonella (http:/ / pubmlst.org/organisms/salmonella-spp). Plasmid replicon typing was performed using a PCR-based replicon typing kit (Diatheva, Fano, Italy). We investigated the presence of 30 major plasmid incompatibility groups circulating among Enterobacteriaceae: IncHI1, HI2, I1, I2, X1, X2, X3, X4, L, M, N, FIA, FIB, FIC, FII, FIIS, FIIK, FIB KN, FIB, KQ, W, $\mathrm{Y}, \mathrm{P} 1, \mathrm{~A} / \mathrm{C}, \mathrm{T}, \mathrm{K}, \mathrm{U}, \mathrm{R}, \mathrm{B} / \mathrm{O}, \mathrm{HIB}-\mathrm{M}$, and FIB-M. Additionally, a mPCR assay (iNtRON Biotechnology, Seongnam, South Korea) was performed to detect virulence factor genes that enable Salmonella to reach the systemic circulation and increase its infectivity ( $c d t B$, inv $A, \operatorname{iro} N, \operatorname{lpf} C, m s g A, \operatorname{org} A, \operatorname{pag} C, \operatorname{pef} A, \operatorname{prg} H, \operatorname{sif} A, \operatorname{sip} B, \operatorname{sit} C, \operatorname{sop} B, \operatorname{spa} N, \operatorname{spi} A, \operatorname{spv} B$, and tolC), as described previously [29].

Conjugation was performed by the filter mating method using azide-resistant $E$. coli J53 as the recipient strain, as described by $\mathrm{Na}$ et al. [30]. Putative transconjugants were 
selected on a Muller-Hinton agar plate supplemented with sodium azide $(150 \mu \mathrm{g} / \mathrm{mL})$ and colistin $(2 \mu \mathrm{g} / \mathrm{mL})$. The transconjugants were confirmed by PCR detection of the $\mathrm{mcr}-1$ gene, as described above. Transfer frequency was calculated based on the number of transconjugants obtained per donor and conjugation efficiency is explained as mean \pm standard deviation of triplicate experiments. Additionally, the antimicrobial susceptibility profile of the transconjugants was determined as described above.

\subsection{Whole-Genome Sequencing and Annotation}

Genomic DNA was extracted and purified using MG genomic DNA purification kit, according to the manufacturer's instructions (MGmed, Seoul, Korea). For PacBio RS II (Pacific Biosciences, Menlo Park, CA, USA) sequencing, $8 \mu \mathrm{g}$ of input genomic DNA was used for 20-kb library preparation. The library insert sizes were optimal; genomic DNA was sheared with g-TUBE (Covaris Inc., Woburn, MA, USA) and purified using AMPure PB magnetic beads (Beckman Coulter Inc., Brea, CA, USA) if the apparent size was $>40 \mathrm{~kb}$. We sequenced the plasmid genome to $149 \times$ depth using the PacBio Sequel platform. De novo assembly and consensus polishing were performed using the Hierarchical Genome Assembly Process (HGAP) 2 package contained in the SMRT version 2.3.0 software. Assembly data were then circularized using circulator 1.4.0. Glimmer 3 [31] was used to predict genes, and annotation was done using a homology search based on the Clusters of Orthologous Groups (COG) database.

The sequences of the mcr-1-carrying plasmid in this study (pK18JST013, GenBank accession number. CP065423) was compared with those of previously reported plasmids (Table S1). Briefly, nucleotide sequences of $m c r-1$ carrying plasmids were downloaded from the GenBank nucleotide database. As the sequences have different starting points, sequences were rotated for accurate alignment so that the start sites of sequences were set as RepA using GAMOLA2 [32]. The sequence of each plasmid was aligned using Blastn (v 2.8.1) and compared using EasyFig (v.2.2.3) [33]. Besides that, average nucleotide identity (ANI) values were calculated with pairwise genome alignment of sequences by using the ANI-blast method implemented in PYANI (v.0.2.9) [34] and the phylogenetic tree is reconstructed based on the ANI values.

\section{Results and Discussion}

The overall proportion of colistin-resistant Salmonella strains $(9.2 \%, 277 / 3018)$ in this study was slightly higher than previous reports from 11 European countries $(5.3 \%$, 92/1774) [35], Japan $(1.2 \%, 1 / 82)$ [36], and Korea (1\%, 1/100) [37] (Table 1). However, it was lower than the finding of Figueiredo et al. [15] $(14.3 \%, 37 / 258)$ from retail meat in Portugal. The majority of colistin-resistant strains $(98.9 \%, 274 / 277)$ belonged to the Salmonella serogroup D (Salmonella Enteritidis (57.7\%) and Salmonella Gallinarum (42.3\%)) (Table S2). Indeed, colistin resistance was observed in $49.2 \%$ of $S$. Enteritidis and $92.8 \%$ of $S$. Gallinarum isolated from chickens. The only colistin-resistant isolate in serogroup B belonged to Salmonella Typhimurium (Isolate no. 18-A02-013), while serogroup(s) of the two colistin-resistant strains were unidentified. The colistin-resistant (MIC $=16 \mu \mathrm{g} / \mathrm{mL}$ ) $S$. Typhimurium was recovered from a healthy pig from Jeju in 2018. The high colistin resistance rate in $S$. Enteritidis and $S$. Gallinarum isolated from chickens in our study could be due to the intrinsic colistin resistance in these serotypes [38], which is related to the presence and composition of $\mathrm{O}$ antigens [39].

Among the colistin-resistant Salmonella strains $(n=277)$, we detected the $m c r-1$ gene in the only $(0.4 \%) S$. Typhimurium strain. In agreement with this study, many researchers have reported a very low prevalence of $m c r-1$ gene in Salmonella strains isolated from food animals and humans in other Asian countries $(0.3 \%-2 \%)[40,41]$ and Europe $(0.1 \%-3.1 \%)[15,35,42]$. In contrast, Yi et al. [14] (14.8\%) and Ma et al. [43] (11.4\%) have found a relatively higher percentage of $m c r-1$ carriage in Salmonella isolated from food animals and humans in China. Previous studies have also detected other MCR-family genes ( $m c r-2$ to $m c r-5$ and $m c r-9)$ in Salmonella spp isolated from different sources [44,45]. 
Our result suggests that healthy pigs are a matter of concern in terms of transmission of mor-1-carrying Salmonella to humans through the food chain. The differences in the number of tested isolates and resistance detection methods should be considered while comparing and contrasting findings from other studies.

Table 1. Prevalence of colistin resistance in Salmonella serogroups isolated from healthy cattle, chickens, and pigs in Korea between 2010 and 2018.

\begin{tabular}{cc}
\hline Serogroups & $\begin{array}{c}\text { Prevalence } \mathbf{\%} \text { ) } \\
\text { (no. of Resistance/no of Tested) }\end{array}$ \\
B 1 & $0.1(1 / 867)$ \\
C2-C3 & $0(0 / 996)$ \\
D1 & $0(0 / 402)$ \\
E1 & $56.1(274 / 488)$ \\
E2 & $0(0 / 125)$ \\
E4 & $0(0 / 1)$ \\
G & $0(0 / 74)$ \\
H & $0(0 / 1)$ \\
K & $0(0 / 1)$ \\
L & $0(0 / 1)$ \\
M & $0(0 / 1)$ \\
NT & $0(0 / 1)$ \\
Total & $3.3(2 / 60)$ \\
\hline
\end{tabular}

Abbreviation: NT, Unidentified

The mcr-1-carrying $S$. Typhimurium in this study (18-A02-013) presented additional resistance to multiple antimicrobials, including resistance to ampicillin, chloramphenicol, streptomycin, sulfisoxazole, and tetracycline (Table 2). This multidrug resistance pattern is characteristic of the European $S$. Typhimurium clones [46,47] and it is strongly associated with pork [48]. Multiple resistance determinants could co-exist with the $m c r-1$ gene in the same plasmid, and this can generate resistance to multiple antimicrobials [13,49]. Our $S$. Typhimurium strain belonged to sequence type (ST) 19. Consistently, mcr-1-carrying $S$. Typhimurium ST19 was identified from patients and retail meat in Brazil [17], China [49], and Denmark [42]. Similarly, Suh and Song [50] have identified S. Typhimurium ST19, although susceptible to colistin, from swine carcasses in Korea. S. Typhimurium ST19 is globally distributed and associated with outbreaks of human gastroenteritis, mainly in Europe and the US [25,51,52]. Additionally, the mcr-1-carrying $S$. Typhimurium identified in this study carried a large repertoire of virulence factor genes (Table 2). Except for iroN and $s i t C$, all the detected virulence factor genes encode products that are related to host cell adhesion, invasion, and intracellular survival [29]. The iroN and sitC genes were related to other traits thought to be important in Salmonella pathogenesis, such as iron acquisition [29,53]. Leite et al. [52] also reported on mcr-9-carrying S. Typhimurium ST19 strain carrying a plethora of virulence factors associated with Salmonella adhesion, stress adaptation, immune evasion, and invasion. Thus, the association of the $m c r-1$ and virulence factor genes with one of the most widely distributed Salmonella strains isolated from pig presented a potential risk to public health.

The association of the $m c r-1$ gene with different plasmids is vital for its dissemination into various hosts. The $\mathrm{mcr}-1$ gene in $S$. Typhimurium strain isolated in this study belonged to the IncI2 plasmid, a finding consistent with those of Torpdah et al. [42] in Denmark and Lu et al. [54] in China. Similarly, other studies in China [40] and Great Britain [55] have reported the link between the $m c r-1$ gene and the IncI2 plasmid in $S$. Typhimurium isolated from patients. The mcr-1-carrying plasmids are highly stable in bacteria even in the absence of polymyxin selection pressure. Thus, the existence of the $m c r-1$ gene embedded into the IncI2 plasmid is a huge concern, because it facilitates the transfer of the $m c r-1$ gene to other bacterial pathogens of animal and human origin, including commensals $[6,55]$. 
Table 2. Characteristics of the mor-1-carrying S. Typhimurium.

\begin{tabular}{|c|c|c|c|c|c|c|c|c|}
\hline Isolate & Source & $\begin{array}{l}\text { Isolation } \\
\text { Year }\end{array}$ & $\begin{array}{l}\text { Resistance } \\
\text { Pattern of } \\
\text { Donor }\end{array}$ & $\begin{array}{l}\text { Sequence } \\
\text { Type }\end{array}$ & $\begin{array}{ll}\text { Conjugation } & \mathrm{R} \\
\text { Efficiency } & \mathrm{F}\end{array}$ & $\begin{array}{l}\text { Resistance } \\
\text { Pattern of } \\
\text { Recipient }\end{array}$ & $\begin{array}{l}\text { Replicon } \\
\text { Type of } \\
\text { Transcon- } \\
\text { jugant }\end{array}$ & $\begin{array}{l}\text { Virulence } \\
\text { Factors }\end{array}$ \\
\hline 18-A02-013 & Healthy Pig & 2018 & $\begin{array}{l}\text { AMP CHL } \\
\text { GEN STR } \\
\text { FIS TET }\end{array}$ & ST19 & $3.0 \pm 0.8 \times 10^{-3}$ & $3 \quad \mathrm{COL}$ & I2 & $\begin{array}{c}\text { spiA, pagC, } \\
m s g A, \operatorname{inv} A, \\
\operatorname{sip} B, \operatorname{prg} H, \\
\text { spaN, orgA, } \\
\text { tolC, } \operatorname{lpfC}, \\
\text { sifA, sopB, } \\
\text { iroN, sitC }\end{array}$ \\
\hline
\end{tabular}

Abbreviations: AMP, Ampicillin; CHL, chloramphenicol; COL, colistin; GEN, gentamicin; STR, streptomycin; FIS, sulfisoxazole; TET, tetracycline.

The conjugation efficiency of the $m c r$ - 1 -carrying IncI2 plasmid in this study $\left(3.0 \pm 0.8 \times 10^{-3}\right)$ was higher than those of the $m c r-1$-carrying IncI2 plasmids reported by Anjum et al. [55] (between $10^{-7}$ and $10^{-9}$ ). However, it was low compared to some of the $\mathrm{mcr}$-1-carrying IncI2 plasmids reported by Lu et al. [54]. The IncI2 plasmids, which have a broad host range, are commonly associated with the acquisition and transfer of new antibiotic resistance genes. Additionally, they are known to adapt to new bacterial hosts [56].

The $m c r-1$ carrying plasmid (pK18JST013) from this study was compared with those of previously reported strains (Table S1); pK18JST013 was clustered with the plasmid pCFSA664-3 that was detected in S. Indiana from chicken in China (Figure 1); pK18JST013 is also related to other $m c r-1$-carrying plasmids detected in E. coli and S. Typhimurium from humans and food animals in Korea and other countries. Additionally, the mcr-1 carrying plasmid IncI2 pK18JST013 (60,864 bp) had a substantial sequence homology (>98\% sequence identity) compared to other IncI2 plasmids. Indeed, insertion sequences were missing upstream of the $m c r-1$ gene compared to the original mcr-1 carrying plasmid from China (pHNSHP45) (Figure 2). The low genetic variability observed among the mcr-1-carrying plasmids indicates no major evolutionary divergences [52]. Thus, the $m c r-1$ carrying plasmid might be transmitted to Salmonella from other mcr-1-positive bacteria such as E. coli which co-exist in gastrointestinal tract food animals [40].

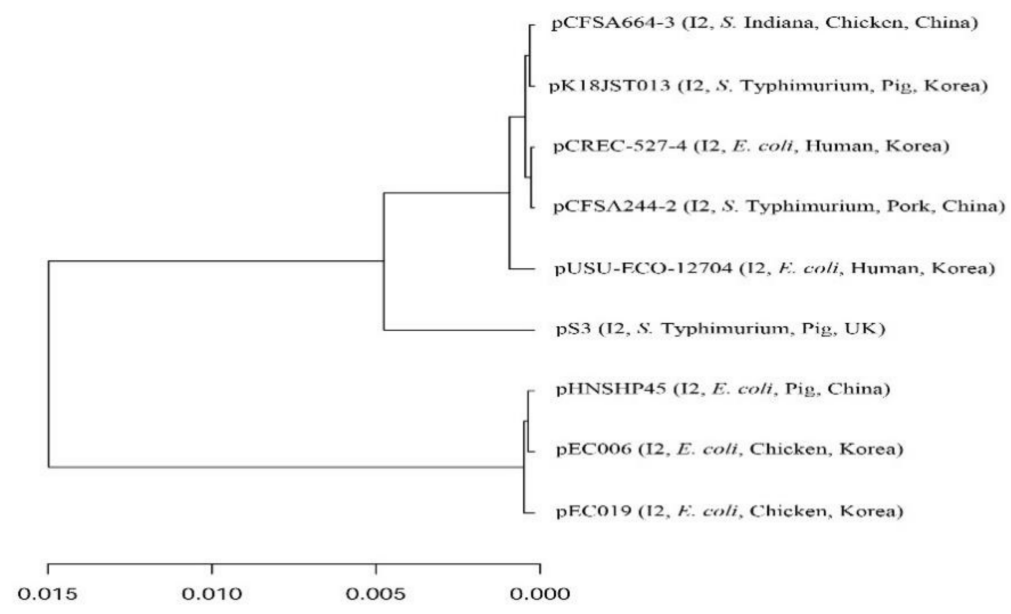

Figure 1. Average nucleotide identity analysis was performed using the ANI-blast method implemented in PYANI (v.0.2.9) and the tree was generated based on the ANI values. The horizontal lines represent the $95 \%$ threshold value. The scale bar represents sequence divergence, i.e., the percentage of nucleotide substitution rate over the length of the genome. Detailed information on the sources and characteristics of the compared plasmids is presented in Table S1. 


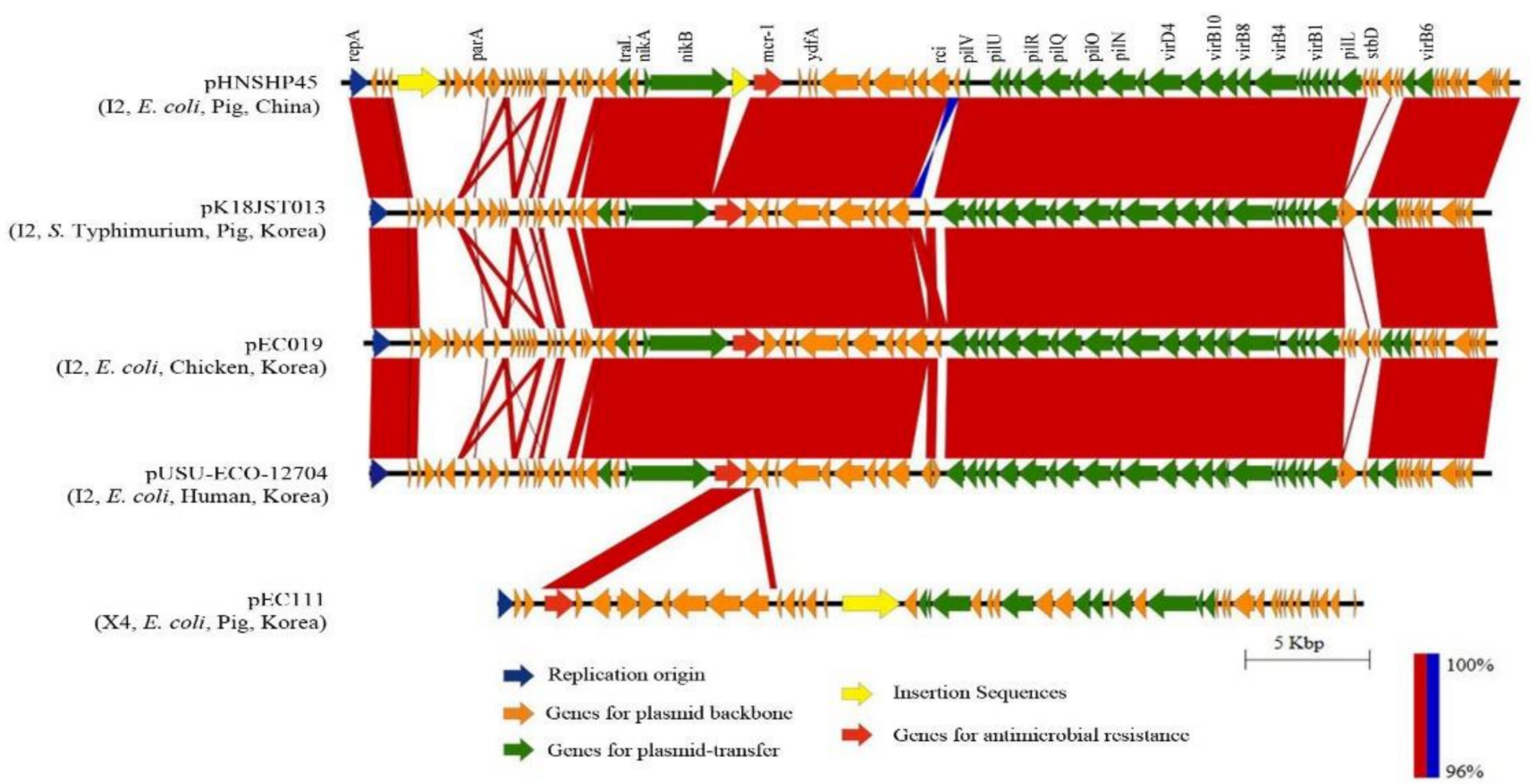

Figure 2. Comparative analyses of the mcr-1-carrying pK18JST013 from Salmonella Typhimurium with mcr-1 carrying plasmids in E. coli strains isolated from food animals and humans. The sequence of each plasmid (Table S1) was aligned using Blastn (v 2.8.1) and compared using EasyFig (v.2.2.3). Highly conserved regions with normal alignment are indicated in red, and regions with inverted alignment are indicated in blue.

In conclusion, although colistin-resistant Salmonella remains rare in food animals in Korea, the detection $m c r-1$ gene in virulent $S$. Typhimurium strain imposes the greatest awareness. This is the first report of $m c r-1$-carrying $S$. Typhimurium in Korea, indicating a recent introduction of this clone into the pig husbandry. This finding emphasizes the role of food animals as potential reservoirs of mcr-carrying S. Typhimurium ST19.

Supplementary Materials: The following are available online at https:/ /www.mdpi.com/2076-260 7/9/2/398/s1. Table S1. Lists of plasmids identified in E. coli and Salmonella isolates recovered from humans and food animals. Table S2. Prevalence of colistin resistance in Salmonella Serogroup B and D isolated from cattle, chickens, and pigs in Korea between 2010 and 2018.

Author Contributions: Conceptualization, D.C.M., S.-K.L., and S.-S.Y.; methodology, S.-J.K., A.F.M., H.Y.K., H.-J.S., and J.-H.C.; validation, A.F.M., S.-J.K., and J.-H.C.; formal analysis, D.C.M. and H.Y.K.; investigation, S.-J.K., A.F.M., H.Y.K., H.-J.S., and J.-H.C.; data curation, D.C.M. and S.-S.Y.; writingoriginal draft preparation, A.F.M., D.C.M., and S.-K.L.; writing-review and editing, A.F.M., D.C.M., and S.-K.L.; supervision, S.-S.Y. and S.-K.L.; project administration, D.C.M. and H.Y.K.; funding acquisition; S.-K.L. and D.C.M. All authors have read and agreed to the published version of the manuscript.

Funding: This research was funded by the Animal and Plant Quarantine Agency, Ministry of Agriculture, Food, and Rural Affairs, South Korea, grant N-1543081-2017-24-01.

Institutional Review Board Statement: Not applicable.

Informed Consent Statement: Not applicable.

Data Availability Statement: The datasets presented in this study have been deposited in the Sequence Read Archive of the National Center for Biotechnology Information (NCBI) (accession number: CP065423).

Conflicts of Interest: The authors declare no conflict of interest. The funders had no role in the design of the study; in the collection, analyses, or interpretation of data; in the writing of the manuscript, or in the decision to publish the results. 


\section{References}

1. Lokken, K.L.; Walker, G.T.; Tsolis, R.M. Disseminated infections with antibiotic-resistant non-typhoidal Salmonella strains: Contributions of host and pathogen factors. Pathog. Dis. 2016, 74, 103. [CrossRef]

2. GBD. The global burden of non-typhoidal Salmonella invasive disease: A Systematic analysis for the global burden of disease study 2017. Lancet 2019, 19, 1312-1324.

3. Korean Center for Disease Control and Prevention (KCDC). Guideline for Control of Waterborne and Foodborne Disease; KCDC: Cheongju, Korea, 2018; pp. 6-8.

4. Grégoire, N.; Aranzana-Climent, V.; Magréault, S.; Marchand, S.; Couet, W. Clinical Pharmacokinetics and Pharmacodynamics of Colistin. Clin. Pharmacokinet. 2017, 56, 1441-1460. [CrossRef] [PubMed]

5. Sun, J.; Zhang, H.; Liu, Y.-H.; Feng, Y. Towards Understanding MCR-like Colistin Resistance. Trends Microbiol. 2018, 26, 794-808. [CrossRef]

6. $\quad$ Liu, Y.-Y.; Wang, Y.; Walsh, T.R.; Yi, L.-X.; Zhang, R.; Spencer, J.D.; Doi, Y.; Tian, G.; Dong, B.; Huang, X.; et al. Emergence of plasmid-mediated colistin resistance mechanism MCR-1 in animals and human beings in China: A microbiological and molecular biological study. Lancet Infect. Dis. 2016, 16, 161-168. [CrossRef]

7. $\quad$ Ling, Z.; Yin, W.; Shen, Z.; Wang, Y.; Shen, J.; Walsh, T.R. Epidemiology of mobile colistin resistance genes mcr-1 to mcr-9. J. Antimicrob. Chemother. 2020, 75, 3087-3095. [CrossRef]

8. Lim, S.K.; Kang, H.Y.; Lee, K.; Moon, D.C.; Lee, H.S.; Jung, S.C. First detection of the mcr-1 gene in Escherichia coli isolated from livestock between 2013 and 2015 in South Korea. Antimicrob. Agents Chemother. 2016, 60, 6991-6993. [CrossRef] [PubMed]

9. Mechesso, A.F.; Moon, D.C.; Kang, H.Y.; Song, H.-J.; Kim, S.-J.; Choi, J.-H.; Kim, M.H.; Na, S.H.; Kim, H.-Y.; Jung, B.Y.; et al. Emergence of mcr-3 carrying Escherichia coli in diseased Pigs in South Korea. Microorganisms 2020, 8, 1538. [CrossRef] [PubMed]

10. Cha, M.H.; Woo, G.J.; Kim, S.K.; Woo, J.H.; Kim, J.; Ryu, J.G.; Kwak, H.S.; Chi, Y.M. Emergence of transferable mcr-9 gene carrying colistin-resistant Salmonella Enterica Dessu ST14 isolated from retail chicken meat in Korea. Foodborne Pathog. Dis. 2020, 17, 720-727.

11. Chiou, C.-S.; Chen, Y.-T.; Wang, Y.-W.; Liu, Y.-Y.; Kuo, H.-C.; Tu, Y.-H.; Lin, A.-C.; Liao, Y.-S.; Hong, Y.-P. Dissemination of mcr-1carrying plasmids among colistin-resistant Salmonella Strains from humans and food-producing animals in Taiwan. Antimicrob. Agents Chemother. 2017, 61, e00338-17. [CrossRef] [PubMed]

12. Suzuki, S.; Ohnishi, M.; Kawanishi, M.; Akiba, M.; Kuroda, M. Investigation of a plasmid genome database for colistin-resistance gene mcr-1. Lancet Infect. Dis. 2016, 16, 284-285. [CrossRef]

13. Yang, Y.Q.; Zhang, A.Y.; Ma, S.Z.; Kong, L.H.; Li, Y.X.; Liu, J.X.; Davis, M.A.; Guo, X.Y.; Liu, B.H.; Lei, C.W.; et al. Co-occurrence of mor-1 and ESBL on a single plasmid in Salmonella enterica. J. Antimicrob. Chemother. 2016, 71, 2336-2338. [CrossRef]

14. Yi, L.; Wang, J.; Gao, Y.; Liu, Y.; Doi, Y.; Wu, R.; Zeng, Z.; Liang, Z.; Liu, J.-H. mcr-1-harboring Salmonella enterica Serovar Typhimurium Sequence Type 34 in Pigs, China. Emerg. Infect. Dis. 2017, 23, 291-295. [CrossRef]

15. Figueiredo, R.; Card, R.M.; Nunez, J.; Pomba, C.; Mendonça, N.; Anjum, M.F.; Da Silva, G.J. Detection of an mcr-1-encoding plasmid mediating colistin resistance in Salmonella enterica from retail meat in Portugal. J. Antimicrob. Chemother. 2016, 71, 2338-2340. [CrossRef]

16. Quesada, A.; Concepción Porrero, M.; Téllez, S.; Palomo, G.; García, M.; Domínguez, L. Polymorphism of genes encoding PmrAB in colistin-resistant strains of Escherichia coli and Salmonella enterica isolated from poultry and swine. J. Antimicrob. Chemother. 2015, 70, 71-74. [CrossRef]

17. Rau, R.B.; De Lima-Morales, D.; Wink, P.L.; Ribeiro, A.R.; Martins, A.F.; Barth, A.L. Emergence of mcr-1 Producing Salmonella enterica serovar Typhimurium from retail meat: First detection in Brazil. Foodborne Pathog. Dis. 2018, 15, 58-59. [CrossRef]

18. Saavedra, S.Y.; Diaz, L.; Wiesner, M.; Correa, A.; Arévalo, S.A.; Reyes, J.; Hidalgo, A.M.; De La Cadena, E.; Perenguez, M.; Montaño, L.A.; et al. Genomic and molecular characterization of clinical isolates of Enterobacteriaceae harboring mcr-1 in Colombia, 2002 to 2016. Antimicrob. Agents Chemother. 2017, 61, e00841-17. [CrossRef] [PubMed]

19. Moon, D.C.; Mechesso, A.F.; Kang, H.Y.; Kim, S.-J.; Choi, J.-H.; Kim, M.H.; Song, H.-J.; Yoon, S.-S.; Lim, S.-K. First report of an Escherichia coli strain carrying the colistin resistance determinant mcr-1 from a dog in South Korea. Antibiotics $2020,9,768$. [CrossRef] [PubMed]

20. Oh, S.-S.; Song, J.; Kim, J.; Shin, J. Increasing prevalence of multidrug-resistant mcr-1-positive Escherichia coli isolates from fresh vegetables and healthy food animals in South Korea. Int. J. Infect. Dis. 2020, 92, 53-55. [CrossRef]

21. Yoon, E.-J.; Hong, J.S.; Yang, J.W.; Lee, K.J.; Lee, H.; Jeong, S.H. Detection of mcr-1 plasmids in Enterobacteriaceae isolates from human specimens: Comparison with those in Escherichia coli isolates from livestock in Korea. Ann. Lab. Med. 2018, 38, 555-562. [CrossRef]

22. Wang, R.; Dorp, L.V.; Shaw, L.P.; Bradely, P.; Wang, Q.; Wang, X.; Jin, L.; Zhang, Q.; Liu, Y.; Rieux, A.; et al. The global distribution and spread of the mobilized colistin resistance gene mor-1. Nat. Commun. 2018, 9, 1179. [CrossRef] [PubMed]

23. Mechesso, A.F.; Moon, D.C.; Kim, S.-J.; Song, H.-J.; Kang, H.Y.; Na, S.H.; Choi, J.-H.; Kim, H.-Y.; Yoon, S.-S.; Lim, S.-K. Nationwide surveillance on serotype distribution and antimicrobial resistance profiles of non-typhoidal Salmonella serovars isolated from food-producing animals in South Korea. Int. J. Food Microbiol. 2020, 335, 108893. [CrossRef] [PubMed]

24. Rebelo, A.R.; Bortolaia, V.; Kjeldgaard, J.S.; Pedersen, S.K.; Leekitcharoenphon, P.; Hansen, I.M.; Guerra, B.; Malorny, B.; Borowiak, M.; Hammerl, J.A.; et al. Multiplex PCR for detection of plasmid-mediated colistin resistance determinants, $m c r-1$, mcr-2, $m c r-3$, mcr-4, and mcr-5 for surveillance purposes. Eurosurveillance 2018, 23, 17-00672. [CrossRef] 
25. Borowiak, M.; Baumann, B.; Fischer, J.; Thomas, K.; Deneke, C.; Hammerl, J.A.; Szabo, I.; Malorny, B. Development of a novel $m c r-6$ to $m c r-9$ multiplex PCR and assessment of $m c r-1$ to $m c r-9$ occurrence in colistin-resistant Salmonella enterica isolates from environment, feed, animals and food (2011-2018) in Germany. Front. Microbiol. 2020, 11, 80. [CrossRef]

26. Clinical and Laboratory Standards Institute (CLSI). Performance Standards for Antimicrobial Susceptibility Testing; Twentieth Informational Supplement; CLSI Document M100: Wayne, PA, USA, 2018.

27. European Committee on Antimicrobial Susceptibility Testing. Breakpoint Tables for Interpretation of MICs and Zone Diameters. EUCAST, 2018, Version 8.1. Available online: http://www.eucast.org (accessed on 17 July 2020).

28. Kidgell, C.; Reichard, U.; Wain, J.; Linz, B.; Torpdahl, M.; Dougan, G.; Achtman, M. Salmonella typhi, the causative agent of typhoid fever, is approximately 50,000 years old. Infect. Genet. Evol. 2002, 2, 39-45. [CrossRef]

29. Skyberg, J.A.; Logue, C.M.; Nolan, L.K. Virulence genotyping of Salmonella spp. with multiplex PCR. Avian Dis. 2006, 50, 77-81. [CrossRef]

30. Na, S.H.; Moon, D.C.; Kang, H.Y.; Song, H.J.; Kim, S.J.; Choi, J.H.; Yoon, J.W.; Yoon, S.S.; Lim, S.K. Molecular characteristics of extended-spectrum $\beta$-lactamase/AmpC-producing Salmonella enterica serovar Virchow isolated from food-producing animals during 2010-2017 in South Korea. Int. J. Food Microbiol. 2020, 322, 108572.

31. Delcher, A.L.; Bratke, K.A.; Powers, E.C.; Salzberg, S.L. Identifying bacterial genes and endosymbiont DNA with Glimmer. Bioinformatics 2007, 23, 673-679. [CrossRef] [PubMed]

32. Altermann, E.; Lu, J.; McCulloch, A. GAMOLA2, a comprehensive software package for the annotation and curation of draft and complete microbial genomes. Front. Microbiol. 2017, 8, 346. [CrossRef]

33. Sullivan, M.J.; Petty, N.K.; Beatson, S.A. Easyfig: A genome comparison visualizer. Bioinformatics 2011, 27, 1009-1010. [CrossRef]

34. Pritchard, L.; Glover, R.H.; Humphris, S.; Elphinstone, J.G.; Toth, I.K. Genomics and taxonomy in diagnostics for food security: Soft-rotting enterobacterial plant pathogens. Anal. Methods 2016, 8, 12-24. [CrossRef]

35. El Garch, F.; De Jong, A.; Bertrand, X.; Hocquet, D.; Sauget, M. mcr-1-like detection in commensal Escherichia coli and Salmonella spp. from food-producing animals at slaughter in Europe. Vet. Microbiol. 2018, 213, 42-46. [CrossRef]

36. Esaki, H.; Morioka, A.; Ishihara, K.; Kojima, A.; Shiroki, S.; Tamura, Y.; Takahashi, T. Antimicrobial susceptibility of Salmonella isolated from cattle, swine, and poultry (2001-2002): Report from the Japanese Veterinary Antimicrobial Resistance Monitoring Program. J. Antimicrob. Chemother. 2004, 53, 266-270. [CrossRef] [PubMed]

37. Lim, S.-K.; Lee, H.-S.; Nam, H.-M.; Jung, S.-C.; Koh, H.-B.; Roh, I.-S. Antimicrobial resistance and phage types of Salmonella isolates from healthy and diarrheic pigs in Korea. Foodborne Pathog. Dis. 2009, 6, 981-987. [CrossRef]

38. European Center for Disease Prevention and Control. The European Union summary report on antimicrobial resistance in zoonotic bacteria from humans, animals, and food in 2014. EFSA J. 2016, 14, 4380.

39. Ricci, V.; Zhang, D.; Teale, C.; Piddock, L.J.V. The O-antigen epitope governs susceptibility to colistin in Salmonella enterica. mBio 2020, 11, e02831-19. [CrossRef]

40. Cui, M.; Zhang, J.; Gu, Z.; Li, R.; Chan, E.W.-C.; Yan, M.; Wu, C.; Xu, X.; Chen, S. Prevalence and molecular characterization of mcr-1-positive Salmonella strains recovered from clinical specimens in China. Antimicrob. Agents Chemother. 2017, 61, e02471-16. [CrossRef]

41. Lai, C.-C.; Lin, Y.-T.; Lin, Y.-T.; Lu, M.-C.; Shi, Z.-Y.; Chen, Y.-S.; Wang, L.-S.; Tseng, S.-H.; Lin, C.-N.; Chen, Y.-H.; et al. Clinical characteristics of patients with bacteraemia due to the emergence of mcr-1-harbouring Enterobacteriaceae in humans and pigs in Taiwan. Int. J. Antimicrob. Agents 2018, 52, 651-657. [CrossRef] [PubMed]

42. Torpdahl, M.; Hasman, H.; Litrup, E.; Skov, R.L.; Nielsen, E.M.; Hammerum, A.M. Detection of mcr-1-encoding plasmid-mediated colistin-resistant Salmonella isolates from human infection in Denmark. Int. J. Antimicrob. Agents. 2017, 49, 261-262. [PubMed]

43. Ma, S.; Lei, C.; Kong, L.; Jiang, W.; Liu, B.; Men, S.; Yang, Y.; Cheng, G.; Chen, Y.; Wang, H. Prevalence, antimicrobial resistance, and relatedness of Salmonella isolated from chickens and pigs on farms, abattoirs, and markets in Sichuan Province, China. Foodborne Pathog. Dis. 2017, 14, 667-677. [CrossRef] [PubMed]

44. Lima, T.; Domingues, S.; Da Silva, G.J. Plasmid-mediated colistin resistance in Salmonella enetrica: A review. Microorganisms 2019, 7, 55. [CrossRef] [PubMed]

45. Luo, Q.; Wang, Y.; Xiao, Y. Prevalence and transmission of mobilized colistin resistance ( $m c r)$ gene in bacteria common to animals and humans. Biosaf. Health 2020, 2, 71-78. [CrossRef]

46. Antunes, P.; Mourão, J.; Pestana, N.; Peixe, L. Leakage of emerging clinically relevant multidrug-resistant Salmonella clones from pig farms. J. Antimicrob. Chemother. 2011, 66, 2028-2032. [CrossRef] [PubMed]

47. Hopkins, K.L.; Kirchner, M.; Guerra, B.; A Granier, S.; Lucarelli, C.; Porrero, M.C.; Jakubczak, A.; Threlfall, E.J.; Mevius, D.J. Multiresistant Salmonella enterica serovar 4,[5],12:i:- in Europe: A new pandemic strain? Eurosurveillance. 2010, 15, 19580.

48. García, P.; Guerra, B.; Bances, M.; Mendoza, M.C.; Rodicio, M.R. IncA/C plasmids mediate antimicrobial resistance linked to virulence genes in the Spanish clone of the emerging Salmonella enterica serotype 4,[5],12:i:-. J. Antimicrob. Chemother. 2010, 66, 543-549. [CrossRef] [PubMed]

49. Lu, J.; Quan, J.; Zhao, D.; Wang, Y.; Yu, Y.; Zhu, J. Prevalence and molecular characteristics of mcr-1 gene in Salmonella typhimurium in a tertiary hospital of Zhejiang Province. Infect. Drug Resist. 2018, 12, 105-110. [CrossRef]

50. Suh, D.K.; Song, J.C. Characterization of multi-drug resistant Salmonella enterica serovar Typhimurium isolated from swine sources. J. Exp. Biomed. Sci. 2005, 11, 115-119. 
51. Hua, M.; Huang, W.; Chen, A.; Rehmet, M.; Jin, C.; Huang, Z. Comparison of Antimicrobial Resistance Detected in Environmental and Clinical Isolates from Historical Data for the US. BioMed Res. Int. 2020, 2020, e4254530-11. [CrossRef]

52. Leite, E.L.; Araújo, W.J.; Vieira, T.R.; Zenato, K.S.; Vasconcelos, P.C.; Cibulski, S.; Givisiez, P.E.; Cardoso, M.R.; Oliveira, C.J. First reported genome of an mcr-9-mediated colistin-resistant Salmonella Typhimurium isolate from Brazilian livestock. J. Glob. Antimicrob. Resist. 2020, 23, 394-397. [CrossRef] [PubMed]

53. Borges, K.A.; Furian, T.Q.; Borsoi, A.; Moraes, H.L.; Salle, C.T.P.; Nascimento, V.P. Detection of virulence-associated genes in Salmonella Enteritidis isolates from chicken in South of Brazil. Pesqui. Veterinária Bras. 2013, 33, 1416-1422. [CrossRef]

54. Lu, X.; Zeng, M.; Xu, J.; Zhou, H.; Gu, B.; Li, Z.; Jin, H.; Wang, X.; Zhang, W.; Hu, Y.; et al. Epidemiologic and genomic insights on mcr-1-harbouring Salmonella from diarrhoeal outpatients in Shanghai, China, 2006-2016. EBioMedicine 2019, 42, 133-144. [CrossRef] [PubMed]

55. Anjum, M.F.; Duggett, N.A.; AbuOun, M.; Randall, L.; Nunez-Garcia, J.; Ellis, R.J.; Rogers, J.; Horton, R.; Brena, C.; Williamson, S.; et al. Colistin resistance in Salmonella and Escherichia coli isolates from a pig farm in Great Britain. J. Antimicrob. Chemother. 2016, 71, 2306-2313. [CrossRef] [PubMed]

56. Wong, M.H.Y.; Liu, L.; Yan, M.; Chan, E.W.C.; Chen, S. Dissemination of IncI2 plasmids that harbor the bla $a_{C T X-M}$ element among clinical Salmonella isolates. Antimicrob. Agents Chemother. 2015, 59, 5026-5028. [CrossRef] [PubMed] 